\title{
Bean pod mottle virus Spread in Insect-Feeding-Resistant Soybean
}

Margaret G. Redinbaugh, United States Department of Agriculture-Agricultural Research Service, Corn and Soybean Research, and Department of Plant Pathology, The Ohio State University-Ohio Agricultural Research and Development Center (OARDC), Wooster 44691; and Julio E. Molineros, Jean Vacha, and Sue Ann Berry, Department of Plant Pathology, Ronald B. Hammond, Department of Entomology, and Laurence V. Madden and Anne E. Dorrance, Department of Plant Pathology, The Ohio State University-OARDC

\begin{abstract}
Redinbaugh, M. G., Molineros, J. E., Vacha, J., Berry, S. A., Hammond, R. B., Madden, L. V., and Dorrance, A. E. 2010. Bean pod mottle virus spread in insect-feeding-resistant soybean. Plant Dis. 94:265-270.

Bean pod mottle virus (BPMV) infection reduces yield and seed quality in soybean. To test the hypothesis that virus incidence and movement within plots would be reduced in soybean with resistance to feeding by the virus' bean leaf beetle (Cerotoma trifurcata) vector, BPMV spread was evaluated in five soybean genotypes at two inoculum levels over 2 years at two locations in Ohio. Soybean genotypes included two insect-feeding-susceptible genotypes (Williams 82 and Resnik), two insect-feeding-resistant, semidwarf genotypes (HC95-15 and HC95-24), and an insect-feeding-susceptible, semidwarf genotype (Troll). BPMV incidence was assessed in individual plants at growth stages R5/R6 and R7/R8 using enzyme-linked immunosorbent assay. Beetle feeding was visually assessed in 2004. Data for infection of individual plants were analyzed using a generalized linear mixed model, with a binomial distribution and logit-link. Within plots, BPMV incidence was highest in Resnik and Williams 82 and significantly lower in Troll. Incidence in HC95-15 was not significantly different than in Williams 82 and Resnik but incidence in HC95-24 was lower than in Resnik. BPMV incidence was also significantly $(P<0.05)$ affected by year, location, inoculum level and sampling date, with increasing incidence over time and higher incidence at the higher inoculum level. Beetle feeding damage was affected by the interaction of location-genotype. Significant spatial aggregation of infected plants was found for most plots but aggregation was independent of host genotype and inoculum level. Although the results indicate that BPMV infection varied by genotype, they do not support the hypothesis that insect-feeding resistance is sufficient to reduce the incidence and spread of BPMV.
\end{abstract}

Soybean (Glycine $\max$ (L.) Merr.) is planted on approximately 28 to 33 million ha each year in the United States (United States Department of Agriculture, ERS, 2007). Improved profitability for an increasing number of producers in the northcentral region of the United States comes from production and marketing of foodgrade soybean for Asian and domestic markets. Soybean sold as food grade must have a higher quality white bean and a clear hilum with no blemishes, including those caused by infection with viruses. In addition, although virus diseases sometimes have only small $(<5 \%)$ negative impacts on yields, these diseases can have

Corresponding author: M. G. Redinbaugh

E-mail: peg.redinbaugh@ars.usda.gov

Current address of J. E. Molineros: Genetic Epidemiology Unit, Arthritis and Immunology Research Program, Oklahoma Medical Research Foundation, 1025 N.E. 13th St., Oklahoma City 73104.

Accepted for publication 30 October 2009

doi:10.1094/PDIS-94-2-0265

This article is in the public domain and not copyrightable. It may be freely reprinted with customary crediting of the source. The American Phytopathological Society, 2010. large economic implications if they are widespread across a region. Recently, Bean pod mottle virus (BPMV) and Soybean mosaic virus (SMV) have been linked with substantially reduced seed quality and yield in the north-central region $(8,11,35)$.

Yield losses as high as $60 \%$ due to regions (27). Recently, 41 genotypes were evaluated in Nebraska and Ohio to assess the impact of BPMV in northern regions (35). In this study, yield was decreased (3 to $29 \%$ ) and seed coat mottling increased (15 to $40 \%$ ) following inoculations with BPMV at soybean growth stages VC and $\mathrm{V} 3$ to V4. Oil and protein composition were also impacted in Nebraska during 1 year of this study (35).

The primary vector of BPMV is the bean leaf beetle (BLB; Cerotoma trifurcata Forster), which has caused intermittent problems over the past 20 years, including feeding damage to both foliage and pods (11). BLBs overwinter as adults and feed on soybean plants as they emerge. The emergent and first generations typically feed on soybean during early-vegetative to mid-reproductive growth stages, while the second generation feeds on pods in the late summer (11). Previous management techBPMV have been reported from southern niques for BLB were aimed primarily at limiting feeding damage to pods in the mid- to late season. However, the greatest damage from viral infections comes from early-season infections, making it important to consider changing insect management strategies $(22,35)$. In Iowa, earlyseason application of lambda-cyhalothrin targeted at the overwintering adults inconsistently reduced the incidence of BPMV as well as seed coat mottling $(3,19)$ but later applications timed to control the soybean aphid did not (25). Although welltimed insecticide applications may be useful for controlling disease caused by BPMV, the long-term sustainability of the approach is questionable $(3,19)$.

The most environmentally sustainable, economically viable approach to managing viral diseases is to identify and deploy virus-resistant germplasm (18). Although no germplasm with complete resistance to BPMV has been identified in commercial soybean (33), there are transgenic lines with partial resistance to BPMV $(26,28)$. Differences in the responses of commercial cultivars to BPMV suggest that tolerance or partial resistance to the virus is present but, thus far, neither qualitative nor quantitative resistance to BPMV has been genetically characterized $(15,35)$. It is possible that an effective, integrated insect-BPMV management program for soybean could use resistance to insect feeding alone or in combination with quantitative resistance to BPMV, or from combining either resistance mechanism with a chemical treatment.

Insect damage on soybean, even in the absence of viruses, can significantly reduce yield, and insect resistance in soybean has been identified and is well characterized (2). Resistance derived from the soybean plant introduction (PI) PI229358 was mapped to a major quantitative trait locus in linkage group $\mathrm{M}$, and is associated with antixenosis and antibiosis to lepidopteran and other insects (34). Resistance from this PI was incorporated into the two semidwarf, determinant soybean cvs. HC95-24 and HC95-15 (5). These lines have antixenotic activity against BLB and were significantly less defoliated than the nonresistant semidwarf cv. Troll under field conditions (12). However, the insect resistance in these lines did not affect BLB population density or pod feeding. 
The objective of this study was to determine whether insect resistance in soybean could limit BPMV spread in soybean. Our hypothesis was that insect-resistant soybean plants would have lower incidence of BPMV infection and result in more aggregated patterns of virus-infected plants relative to insect-susceptible genotypes. Results from this project will be useful in determining whether there is a genetic alternative to use for virus resistance for management of BPMV.

\section{MATERIALS AND METHODS}

Materials. Five soybean genotypes were used: HC95-15 and HC95-24, two semidwarf breeding lines with resistance to insect feeding $(5,13)$; Troll (6), a semidwarf genotype that is susceptible to insect feeding; and two insect-susceptible, indeterminant lines of normal height, Resnik and Williams $82(1,23)$. All genotypes were maintained at the Ohio Agricultural Research and Development Center (OARDC), Wooster. An Ohio isolate of BPMV (8) belonging to subgroup II (35) was obtained from soybean and maintained by serial transmission in soybean cv. Harosoy seedlings.

Experimental design. Experiments were conducted during 2003 and 2004 at the OARDC near Wooster, OH (hereinafter referred to as Wooster) and at the Northwestern Agricultural Research Branch of the OARDC near Custar, OH (hereinafter referred to as NW). A randomized crossed factorial experimental design was used. Each plot was a combination of genotype and initial inoculum level, and there were four replicates of each plot in each experiment. To minimize the effects of taller genotypes on the semidwarf genotypes (e.g., shading) and to limit the interplot interference for beetle feeding, a 9.1-m border surrounded each plot (31). Individual plots consisted of 12 6.1-m rows, 0.38 $\mathrm{m}$ apart. Individual plants were marked for inoculation or sampling using different colors of plastic ribbon tied loosely at the base of the plant. For low- and highinoculum treatments, 2 or 20 plants, respectively, in the center of each plot were inoculated with BPMV at the unifoliate stage as previously described (35). One inoculated plant from each plot was marked for sampling to monitor mechanical transmission efficiency. In the center four rows of each plot, noninoculated plants for subsequent sampling were selected and marked every $0.3 \mathrm{~m}$ in each row. Distances from each identified plant to the nearest inoculated plant were measured when plants were at the V2 to V3 stage. The two outside rows of each plot were considered a buffer, and five plants from each outer row were sampled at each date to monitor potential influx of BPMV from outside the plot. Planting, inoculation, sampling, insect-feeding rating, and harvest dates are shown in Table 1.

Fields were given preemergence herbicide treatments with Frontier 6.0 (BASF, Research Triangle Park, NC), Sencor DF (Bayer, Research Triangle Park, NC), and Canopy XL (DuPont, Wilmington, DE) at NW, and Roundup (Monsanto, St. Louis) and 2-4-D at Wooster. Standard agronomic practices coupled with post-emergence cultivation and treatment with Select 2EC (Agrisolutions, St. Paul, MN) and Crop Oil were used to control weeds in border areas.

Rating virus symptoms and insect feeding. On each sampling date (Table 1), a single leaf from the uppermost possible node of individual ribbon-marked noninoculated and inoculated plants was harvested into a 5-mil plastic bag (no. FSB4062; Fisher Scientific). Samples were transported on ice and stored at $-80^{\circ} \mathrm{C}$ prior to enzyme-linked immunosorbent assay (ELISA) analyses. Insect feeding, primarily due to BLB, was rated beginning 2 weeks after the emergence of the first generation of BLB when feeding became noticeable. A 0-to-3 ordinal scale was used, with $0=$ no feeding, $1=$ low levels of feeding, 2 = moderate levels of feeding, and 3 = high levels of feeding. When trace evidence of feeding was observed, a rating of 0.5 was given.

BPMV incidence. Leaf samples were analyzed for the presence of BPMV using $\mathrm{F}(\mathrm{ab})_{2}$ or protein A sandwich (PAS) ELISA (9,35). Greenhouse-grown BPMV-infected

Table 1. Dates for planting, virus inoculation, insect feeding rating, and sampling ${ }^{\mathrm{w}}$

\begin{tabular}{llllcc}
\hline Activity & Stage $^{\mathbf{x}}$ & Wooster 2003 & NW 2003 & Wooster 2004 & NW 2004 \\
\hline Plant & $\ldots$ & 27 May & 28 May & 13 May & 6 May \\
Inoculation & V1 & 23 June & 18 June & 1 June & 25 May \\
BLB feeding & $\ldots$ & $\ldots$ & $\ldots$ & 8 August & 19 July \\
& $\ldots$ & & 25 August & 24 August \\
Early sampling & R5/R6 & 26-27 August & 13-14 August & 10 August & 9 August \\
Late sampling & R7/R8 & 18 September & 17 September & 30 August & 2 September \\
Harvest & $\ldots$ & 14 October & 20 October & 26 October & 12 October \\
\hline
\end{tabular}

${ }^{\mathrm{w}}$ Locations were the Ohio Agricultural Research and Development Center (OARDC) near Wooster, $\mathrm{OH}$ (Wooster) and the Northwestern Agricultural Research Branch of the OARDC near Custar, OH (NW).

${ }^{x}$ Growth stage of soybean plants when the activity was done.

${ }^{y}$ Bean leaf beetle (BLB) feeding was rated in 2004 using a 1-to- 3 scale as described in the Materials and Methods. Feeding was very low in 2003; thus, no data were taken.

${ }^{\mathrm{z}}$ Leaf samples were collected to test for the presence of Bean pod mottle virus by enzyme-linked immunosorbent assay. and healthy soybean plants served as positive and negative controls, respectively. Samples were considered positive if the change in absorbance at $405 \mathrm{~nm} / \mathrm{min}$ was more than twice that of the healthy controls (32).

Statistical analysis. Data were analyzed to determine the effects of genotype and initial inoculum on disease incidence at different assessment times in the different locations and years, and to determine the spatial pattern of BPMV-infected plants within plots.

Generalized linear mixed models $(10,20)$ were fitted to the disease incidence data using the GLIMMIX procedure as implemented in version 9.1 of SAS (SAS, Inc., Cary, NC). Model parameters were estimated using restricted pseudolikelihood. It was assumed that infected plants had a binomial distribution; with this distribution, the logit was chosen as the link function. Fixed-effects factors were year, location, genotype, inoculum density, and sampling date. Type- $3 F$ tests were used to determine significance of these effects and their interactions (20), based on utilization of the Kenward-Roger degrees-of-freedom approximation. The distance of each sampled plant to the closest inoculated plant was a random effect in the model. Because plants were sampled twice (early and late in the season) for assessment of BPMV infection to account for different beetle generations, this factor was defined as a repeated measure. To account for properties of the experimental design, the following additional random effects were included in the model: block within location-year combination; plot (combination of inoculum density and genotype) within block-location-year; and assessment time within plot-blocklocation-year. No additional overdispersion term was needed in the model because the deviance was approximately equal to the residual degrees of freedom (L. V. Madden, unpublished).

Additional analyses were performed to determine the effect of the above fixedeffects factors on disease incidence in the border rows and in the inoculated plants only. Analysis of the border rows (i.e., the outside rows of each plot) was done to determine the extent of virus movement into plots from other plots or from other fields. Analysis of the inoculated plants was done to determine the efficiency of inoculations. The above-listed generalized linear mixed model was used for these analyses, with the omission of the distance effect.

The effects of insect feeding on disease incidence were tested for data from 2004 using a nonparametric marginal effects analysis $(4,29)$. This approach is for ordinal rating scales (29). The so-called "ANOVA-type statistic" (4) was used to determine the effects of location, genotype, inoculum level, rating time, and their in- 
teractions on the estimated "marginal effects" of rating values. The marginal-effect estimates are derived from the rankings of the data.

Spatial aggregation tests were carried out to determine if the observed patterns of BPMV-infected plants within plots complied with complete spatial randomness (CSR). Ripley's $K$ function (and associated statistics) was calculated for the pattern of diseased plants in each plot at each assessment time (22). The macro in SAS written by Moser was used for the analysis (24).

\section{RESULTS}

BPMV incidence in inoculated plants. Leaves from an inoculated plant in each plot were collected on both sampling dates and tested for BPMV by ELISA (Table 2). There was no significant effect of location, genotype, or inoculum level on the logit of disease incidence $(P>0.30)$. There was a significant effect of year and time of disease assessment $(P \leq 0.01)$ on the logits, with this latter effect being consistent with an increase in disease intensity through the season. There were no significant interactions for any of the factors $(P>0.30)$. Because of the lack of interactions, only main effect least-squares means of disease incidence (based on the inverse-link function of the estimated logits) are given in Table 2. Incidence for inoculated plants was significantly higher in 2003 than in 2004 and, as anticipated, incidence was higher for the second disease assessment compared with the first assessment. The very similar incidence values for the locations and inoculum levels (because only the inoculated plants were being analyzed here) suggest that the inoculation protocol was reasonably effective. The similar incidence values for the five genotypes (Table 2) confirms that there were no great differences in virus susceptibility among the genotypes when the vector was bypassed via mechanical inoculations.

BPMV incidence in border rows. Virus incidence in border rows was determined to estimate the magnitude of BPMV immigration into the experimental plots. There were significant effects of year, location, genotype, and time of assessment on the logit of disease incidence $(P \leq 0.01$; Table 2). However, inoculum level did not have a significant effect on the incidence in the border rows $(P>0.30)$, which was anticipated, because the border rows were at the maximum distance from the inoculated plants in each plot. There were no significant interactions $(P>0.20)$ for any of the factors; thus, only the main-effect means of incidence (as above, based on the inverse-link of the logit of incidence) are shown (Table 2). Incidence was higher in 2003 than 2004, and was higher at NW than in Wooster. This suggests that there were differences in vector activity, background inoculum, or environmental condi- tions for vector movement and transmission between the locations and years. The significant effect of genotype was primarily manifested by the lower disease incidence for Troll (9\%) than for the other genotypes (28 to $33 \%$ ) (Table 2), which all had very similar levels of BPMV incidence. Thus, insect-feeding resistance had little impact on incidence in border rows.

BLB feeding. BLB feeding was too low to be measured in 2003 but could be assessed in 2004 (Table 3). Based on the nonparametric marginal effects analysis, there were significant effects of location, genotype, sampling date, and the interactions of location-genotype and locationsampling date $(P \leq 0.01)$. As anticipated, initial inoculum level was not significant $(P>0.30)$. No other effects or interactions were significant $(P>0.30)$.
Because of the interactions, the effect of sampling date on feeding damage depended on location, and the effect of genotype also depended on location. At Wooster, beetle-feeding damage was greater at the later sampling date but did not change with time at NW (data not shown). At NW, feeding damage was highest for Resnik and Williams 82 and lower for the three semidwarf genotypes regardless of insectfeeding resistance (Table 3). At Wooster, feeding damage was lower overall compared with NW, although there was a similar pattern among the genotypes. The highest feeding damage occurred on Resnik, which was significantly higher than that found for HC95-24 or HC95-15 (Table 3). However, damage for these later two genotypes was not different from Troll or Williams 82 at Wooster.

Table 2. Bean pod mottle virus (BPMV) incidence in border rows and sampled inoculated plants

\begin{tabular}{|c|c|c|c|c|}
\hline \multirow[b]{2}{*}{ Effect } & \multirow[b]{2}{*}{ Growth $^{\mathrm{x}}$} & \multirow[b]{2}{*}{ Resistance $^{\mathrm{y}}$} & \multicolumn{2}{|c|}{ BPMV incidence $(\%)^{\mathrm{w}}$} \\
\hline & & & Border rows & Inoculated plants \\
\hline \multicolumn{5}{|l|}{ Genotype } \\
\hline HC95-24 & SD & $\mathrm{R}$ & $32.8 \mathrm{a}$ & $63.8 \mathrm{a}$ \\
\hline HC95-15 & SD & $\mathrm{R}$ & $27.8 \mathrm{a}$ & $80.8 \mathrm{a}$ \\
\hline Resnik & ID & $\mathrm{S}$ & $33.4 \mathrm{a}$ & $77.4 \mathrm{a}$ \\
\hline Troll & SD & $\mathrm{S}$ & $9.4 \mathrm{~b}$ & $61.7 \mathrm{a}$ \\
\hline Williams82 & ID & $\mathrm{S}$ & $32.8 \mathrm{a}$ & $75.2 \mathrm{a}$ \\
\hline \multicolumn{5}{|l|}{ Year } \\
\hline 2003 & $\ldots$ & $\ldots$ & $44.2 \mathrm{a}$ & $85.0 \mathrm{a}$ \\
\hline 2004 & $\ldots$ & $\ldots$ & $12.9 \mathrm{~b}$ & $54.8 \mathrm{~b}$ \\
\hline \multicolumn{5}{|l|}{ Location $^{z}$} \\
\hline Wooster & $\ldots$ & $\ldots$ & $12.8 \mathrm{~b}$ & $75.6 \mathrm{a}$ \\
\hline NW & $\ldots$ & $\ldots$ & $44.6 \mathrm{a}$ & $69.0 \mathrm{a}$ \\
\hline \multicolumn{5}{|l|}{ Inoculum } \\
\hline High inoculum & $\ldots$ & $\ldots$ & $27.4 \mathrm{a}$ & $71.4 \mathrm{a}$ \\
\hline Low inoculum & $\ldots$ & $\ldots$ & $23.8 \mathrm{a}$ & $73.5 \mathrm{a}$ \\
\hline \multicolumn{5}{|l|}{ Sampling date } \\
\hline Early & $\ldots$ & $\ldots$ & $16.7 \mathrm{~b}$ & $66.0 \mathrm{~b}$ \\
\hline Late & $\ldots$ & $\ldots$ & $36.9 \mathrm{a}$ & $78.0 \mathrm{a}$ \\
\hline
\end{tabular}

${ }^{w}$ BPMV infection status of individual plants was determined using enzyme-linked immunosorbent assay. Five individuals from each border row and one inoculated plant of each plot were tested. Disease incidence $(\%)$ for the main-effect levels was estimated with the inverse-link function, after first fitting a generalized linear mixed model to the data with a logit-link function. Numbers followed by the same letter (for each main effect) are not statistically different $(P=0.05)$.

${ }^{x}$ Growth habit of genotype: semidwarf (SD) or indeterminant (ID).

${ }^{y}$ Insect feeding of genotype: resistant $(\mathrm{R})$ or susceptible $(\mathrm{S})$.

${ }^{\mathrm{z}}$ Locations were the Ohio Agricultural Research and Development Center (OARDC) near Wooster, $\mathrm{OH}$ (Wooster) and the Northwestern Agricultural Research Branch of the OARDC near Custar, OH (NW).

Table 3. Median beetle feeding damage and corresponding nonparametric marginal effect for five soybean genotypes at two locations in $2004^{\mathrm{w}}$

\begin{tabular}{|c|c|c|c|c|c|c|}
\hline \multirow[b]{2}{*}{ Genotype } & \multirow[b]{2}{*}{ Growth $^{y}$} & \multirow[b]{2}{*}{ Resistance $^{\mathrm{z}}$} & \multicolumn{2}{|c|}{ Median } & \multicolumn{2}{|c|}{ Marginal effect ${ }^{x}$} \\
\hline & & & Wooster & NW & Wooster & NW \\
\hline НC95-24 & SD & $\mathrm{R}$ & 0.75 & 1.50 & $0.28 \mathrm{~b}$ & $0.42 \mathrm{~b}$ \\
\hline НC95-15 & SD & $\mathrm{R}$ & 0.75 & 1.50 & $0.27 \mathrm{~b}$ & $0.45 \mathrm{~b}$ \\
\hline Resnik & ID & $\mathrm{S}$ & 1.25 & 2.00 & $0.47 \mathrm{a}$ & $0.81 \mathrm{a}$ \\
\hline Troll & SD & $\mathrm{S}$ & 1.00 & 1.75 & $0.36 \mathrm{ab}$ & $0.61 \mathrm{~b}$ \\
\hline Williams82 & ID & S & 1.00 & 3.00 & $0.42 \mathrm{ab}$ & $0.91 \mathrm{a}$ \\
\hline
\end{tabular}

${ }^{\mathrm{w}}$ Locations were the Ohio Agricultural Research and Development Center (OARDC) near Wooster, $\mathrm{OH}$ (Wooster) and the Northwestern Agricultural Research Branch of the OARDC near Custar, OH (NW).

$x$ Analysis based on marginal effects (a function of ranks). Because of a significant interaction, comparisons of genotypes were done for each location separately. Marginal effects within a column followed by the same letter are not significantly different $(P=0.05)$.

${ }^{y}$ Growth habit of genotype: semidwarf (SD) or indeterminant (ID).

${ }^{\mathrm{z}}$ Insect feeding of genotype: resistant (R) or susceptible (S). 
BPMV incidence within plots. The generalized linear mixed model successfully fitted to the logits for disease incidence in relationship to distance from the inoculum source and the factors of year, location, genotype, inoculum level, and sampling date. All the main effects (year, location, genotype, inoculum level, and sampling date) were significant $(P \leq$ 0.02 ) based on type-3 $F$ tests (20) but none of the interactions were significant
$(P>0.30)$. Both the least-squares logit means for the main-effect levels and the corresponding values of estimated disease incidence (based on the inverse-link function) are given in Table 4. Disease incidence was significantly higher in 2003 than in 2004, and higher at the NW location than at Wooster. Similarly, disease incidence was higher in border rows in 2003 (Table 2). As anticipated, BPMV incidence increased between the first and

Table 4. Estimated logits of Bean pod mottle virus incidence in soybean plots with disease incidence estimated using the inverse link function for levels of the main effects of genotype, year, location, inoculum level and sampling date

\begin{tabular}{|c|c|c|c|c|}
\hline Effect & Growth habitw & Insect resistance ${ }^{x}$ & Logit (standard error) & Incidence $(\%)^{\mathrm{y}}$ \\
\hline \multicolumn{5}{|l|}{ Genotype } \\
\hline HC95-24 & SD & $\mathrm{R}$ & $-0.58(0.23)$ & $35.9 \mathrm{bc}$ \\
\hline HC95-15 & SD & $\mathrm{R}$ & $-0.47(0.22)$ & $38.4 \mathrm{abc}$ \\
\hline Resnik & ID & $\mathrm{S}$ & $0.05(0.23)$ & $51.3 \mathrm{a}$ \\
\hline Troll & SD & $\mathrm{S}$ & $-0.79(0.23)$ & $31.3 \mathrm{c}$ \\
\hline Williams 82 & ID & $\mathrm{S}$ & $-0.04(0.22)$ & $49.1 \mathrm{ab}$ \\
\hline \multicolumn{5}{|l|}{ Year } \\
\hline 2003 & $\ldots$ & $\ldots$ & $0.00(0.18)$ & $50.0 \mathrm{a}$ \\
\hline 2004 & $\ldots$ & $\ldots$ & $-0.73(0.18)$ & $32.6 \mathrm{~b}$ \\
\hline \multicolumn{5}{|l|}{ Location $^{\mathrm{z}}$} \\
\hline Wooster & $\ldots$ & $\ldots$ & $-0.94(0.18)$ & $28.0 \mathrm{~b}$ \\
\hline NW & $\ldots$ & $\ldots$ & $0.22(0.18)$ & $55.4 \mathrm{a}$ \\
\hline \multicolumn{5}{|l|}{ Inoculum } \\
\hline High & $\ldots$ & $\ldots$ & $-0.15(0.16)$ & $46.2 \mathrm{a}$ \\
\hline Low & $\ldots$ & $\ldots$ & $-0.58(0.17)$ & $36.0 \mathrm{~b}$ \\
\hline \multicolumn{5}{|l|}{ Sampling date } \\
\hline Early & $\ldots$ & $\ldots$ & $-0.63(0.14)$ & $35.0 \mathrm{~b}$ \\
\hline Late & $\ldots$ & $\ldots$ & $-0.10(0.15)$ & $47.6 \mathrm{a}$ \\
\hline
\end{tabular}

${ }^{\mathrm{w}}$ Growth habit of genotype: semidwarf (SD) or indeterminant (ID).

$\mathrm{x}$ Insect feeding of genotype: resistant (R) or susceptible (S).

y Numbers followed by the same letter are not significantly different $(P=0.05)$ for each of the maineffect levels. Mean separations were based on the logits but letters are shown next to incidence values for clarity.

${ }^{\mathrm{z}}$ Locations were the Ohio Agricultural Research and Development Center (OARDC) near Wooster, $\mathrm{OH}$ (Wooster) and the Northwestern Agricultural Research Branch of the OARDC near Custar, OH (NW).

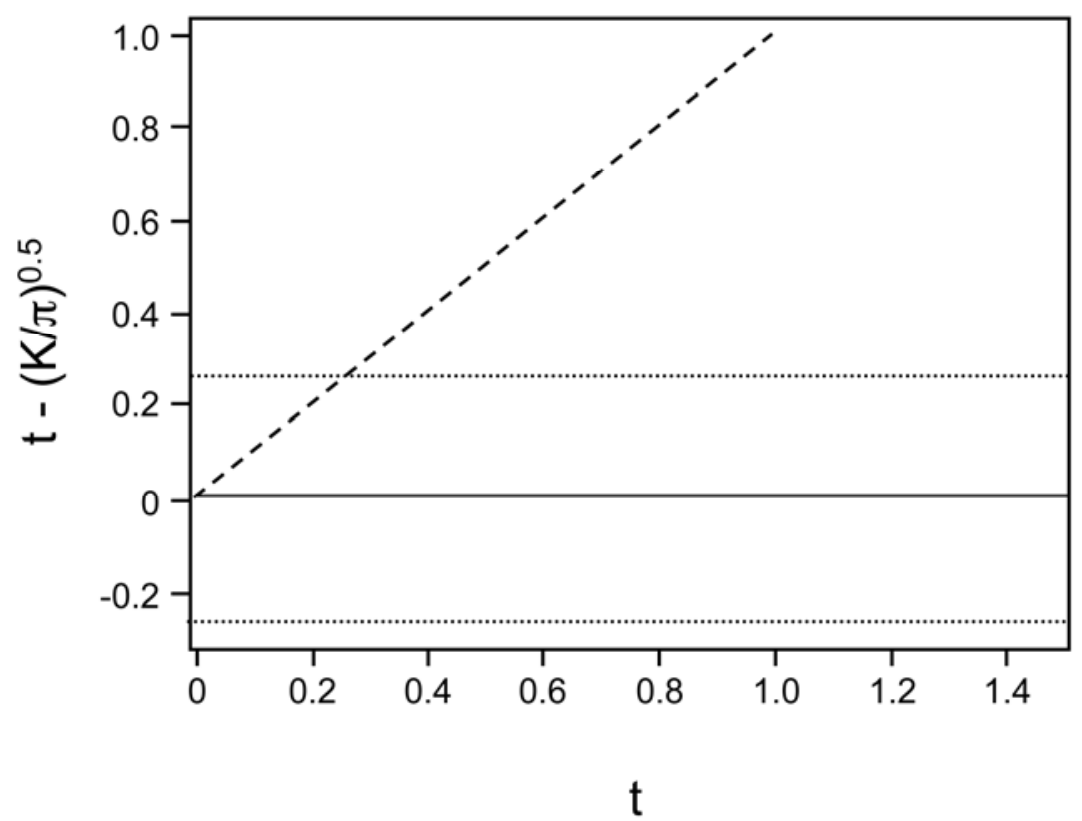

Fig. 1. Analysis of spatial aggregation of virus-infected plants within a plot. The solid horizontal line indicates complete spatial randomness (CSR) for virus incidence, and the two dotted horizontal lines indicate the $95 \%$ confidence limits for the CSR. The dashed line is the Ripley's normalized $K$ function in relation to distance $(\mathrm{t})$ between plants for the plot, and indicates significant aggregation of infected plants because it exceeded the confidence limit.

second sampling dates at both locations and years.

Disease incidence was significantly higher in plots with the high initial inoculum level than in plots with the low initial inoculum level (46 versus 36\%). This suggests that the inoculated plants did serve as an inoculum source for subsequent disease spread.

Genotypes could be grouped into three overlapping groups based on the logits or estimated values of disease incidence (Table 4). The highest incidence values were for Resnik and Williams 82, followed by HC95-15. The lowest disease incidence was for Troll but the mean for this genotype was not significantly different from the means for HC95-24 and HC95-15.

The estimated coefficient for the random-distance effect in the generalized linear mixed model was -0.19 (standard error $=0.02$ ), in units of logits per meter, which was significantly different from 0 based on a Wald standard-normal test statistic. That is, the mean logit declined by 0.19 units for each $1-\mathrm{m}$ increase in distance from the initial infected plants. Because of the nonlinear relation between logits and incidence (22), the decline in disease incidence with the unit increase in distance depends on the particular disease incidence being considered. At a disease incidence of $50 \%$, for instance, mean incidence was predicted to decline by $5 \%$ for a $1-\mathrm{m}$ increase in distance. For a 5-m increase in distance, mean incidence was predicted to decline to $27 \%$ if incidence at the initial inoculum source was $50 \%$. Thus, the disease gradients, although significantly different from 0 , were not steep in the plots.

Distribution of BPMV infected plants within plots. The normalized Ripley $K$ statistic (22) was used to identify aggregation within plots, and an example is shown in Figure 1. If $t$ is distance between infected plants, then the normalized $K$ is given as $t-(K / \pi)^{0.5}$. The normalized $K$ is plotted versus $t$ for the observed data, together with the $95 \%$ confidence envelope for CSR, the latter being calculated from simulated random permutations of the observed data. In the example, most of the normalized $K$ was outside the CSR envelope; thus, BPMV incidence was significantly aggregated within this plot. Based on these calculations for all the 160 plots (corresponding to 2 years, two locations, two initial inoculum levels, five genotypes, and four blocks), BPMV-infected soybean plants were significantly aggregated (clustered) in 98 of 160 plots. For 19 of the remaining 62 plots, analysis was not possible, because there were fewer than two noninoculated infected plants. In the remaining 43 plots, no significant spatial aggregation was detected. No apparent relationship between the plots with spatially aggregated infected plants was found with location, year, genotype, or inoculum 
level (data not shown). For instance, plots with aggregated patterns were found for all genotypes. The general aggregation of infected plants in plots was consistent with the significant distance effect found above in fitting the generalized linear mixed model to the data.

\section{DISCUSSION}

In these experiments, we tested the hypothesis that BPMV movement would be limited in soybean genotypes carrying resistance to BLB feeding relative to movement in nonresistant genotypes. The hypothesis was based on a preliminary experiment done in 2002, in which BPMV incidence in the two insect-feedingresistant genotypes was significantly lower than in Williams 82 and Resnik (data not shown). In the current study, both the initial inoculum level and soybean genotype had significant effects on BPMV incidence within plots. However, although BPMV incidence in the insect-resistant genotypes HC95-24 and HC95-15 was lower than in the insect-susceptible genotype Resnik, it was not significantly different than in Williams 82 (Table 4). Moreover, BPMV incidence in the insect-susceptible, determinant, semidwarf genotype Troll was no different from that in the insect-resistant genotypes, indicating that insect resistance did not affect BPMV incidence in this study. More clustering of infected plants was also expected for the insect-resistant genotypes HC95-24 and HC95-15 relative to insect-susceptible genotypes. However, there was no association of plots showing spatial aggregation with initial inoculum level or genotype. Thus, our hypothesis was not supported.

The lower incidence of BPMV in Troll was unexpected, because this line was previously shown to be more susceptible to beetle feeding (12). The lower BPMV incidence in Troll could be due to some resistance to BPMV multiplication or movement in Troll, or the cultivar might have some resistance to acquisition or inoculation of BPMV by BLB. As a measure of how much virus was moving into the plots from outside, BPMV incidence was determined in border rows (Table 2). If there were no difference in the ability of BLB to transmit BPMV to the five genotypes, no differences in BPMV incidence among genotypes would be predicted in border rows. There were, in fact, differences among genotypes for BPMV incidence in border rows, with Troll having significantly lower incidence than the other four genotypes. However, there was no significant effect of genotype on BPMV incidence in inoculated plants (Table 2) and, in greenhouse experiments, all five genotypes were similarly infected at nearly $100 \%$ incidence after mechanical inoculation with BPMV (data not shown). In addition, greenhouse experiments indicated no significant differences in the ability of the
Mexican bean beetle (Epilachna varivestis Mulsant) to transmit BPMV to Williams 82, Troll, and HC95-24 in "no choice" experiments (data not shown). Together, this suggests that differences in susceptibility or transmissibility were not responsible for the lower incidence of BPMV in Troll.

Madden and co-workers $(17,21)$ demonstrated that virus disease spread is the product of vector density, movement rate, and inoculation or acquisition rate. There is no evidence for BPMV replication in its BLB vector; therefore, continual interactions between the beetle and infected plants are required for virus spread (16). The antixenotic insect resistance in HC9524 and HC95-15 (12) was not effective for controlling BPMV incidence within plots (Table 4). Because inoculation and acquisition is directly dependent on vector feeding (21), the rates of inoculation and acquisition per feeding time were clearly high enough for epidemics to occur under different feeding levels. Supporting this notion is the fact that higher BPMV incidence occurred in 2003, when beetle feeding was too low to measure (Table 2). Thus, reduction in inoculation or acquisition through reductions in total vector feeding does not appear to be an important control approach for this pathosystem. Theoretical research on the epidemics caused by nonpersistently transmitted virus leads to similar conclusions (21). Other studies have indicated a major role for BLB population density in BPMV incidence, where insecticide treatments timed to lower beetle populations reduced BPMV incidence $(3,19)$. Insecticide alone was not sufficient for overall disease control, because insecticide treatments timed to control soybean aphids were ineffective (25).

There are instances where genetically controlled insect resistance has been useful for controlling viral diseases for viruses that are transmitted in a semipersistent or persistent manner. For example, quantitative trait loci for insect resistance conferred moderate disease resistance to the persistently transmitted Maize stripe virus (MStV) and Maize mosaic virus (MMV) in maize (7). BPMV does not enter into the hemolymph and, therefore, is not transmitted in a circulative manner like MStV and MMV. Nonetheless, BPMV persists for fairly long periods of time in the gut of the vector (30). In this way, the BPMV-BLB system is similar to transmission of Wheat streak mosaic virus by the wheat curl mite (Aceria tosichella), and wheat curl mite resistance has been successfully used to control Wheat streak mosaic virus in wheat (14).

It is possible that, under the conditions of these experiments, the expression of insect feeding resistance in HC95-15 and HC95-24 was not sufficient to control BPMV incidence among the semidwarf genotypes. Insect resistance did not affect
BPMV incidence in border rows or within plots (Tables 2 and 4). Although previous studies indicated little difference between the insect-resistant and -susceptible lines for beetle population density or for pod feeding (12), HC95-15 and HC95-24 had lower levels of defoliation during the growing season relative to Troll, and we had hypothesized that early-season control of BLB feeding would reduce BPMV incidence. Early-season application of insecticide alone to control BLB in soybean was not effective for reducing BPMV incidence; however, combining early-season control with a second application timed to control the first generation of BLB was effective (3). Genotypes with season-long resistance to insect feeding, especially ones with antibiosis to leaf and pod feeding by beetles, could provide better protection from BPMV than those tested here.

Relative to susceptible commercial soybean cultivars (e.g., Williams 82), BPMV incidence could be reduced by growing appropriate soybean genotypes. In particular, BPMV incidence was lower in the determinant, semidwarf genotype Troll than in standard indeterminant cultivars. The lower observed virus incidence was not associated with insect feeding resistance derived from PI229358, because Troll does not carry this resistance. Further investigation to determine the cause of reduced virus incidence in Troll and screening of soybean germplasm for antibiotic resistance to leaf and pod feeding may be warranted. However, it is clear that identifying and characterizing quantitative resistance to BPMV in soybean germplasm remains a priority for developing optimal disease management.

\section{ACKNOWLEDGMENTS}

Salaries and research support were provided by State and Federal funds appropriated to the Ohio Agricultural Research and Development Center, The Ohio State University. This research was funded in part by the United States Department of Agriculture, Cooperative State Research, Education, and Extension Service, North Central Integrated Pest Management, Ohio Seed Improvement Association, and Ohio Soybean Check-Off grants. We thank B. Bardall and M. Davis for establishing and maintaining the field plots; and J. Todd, S. Chiera, D. de la Pina, and E. Helliwell for technical assistance.

\section{LITERATURE CITED}

1. Bernard, R. L., and Cremeens, C. R. 1988. Registration of Williams 82 soybean. Crop Sci. 28:1027-1028.

2. Boerma, H. R., and Walker, D. R. 2005. Discovery and utilization of QTLs for insect resistance in soybean. Genetica 123:181-189.

3. Bradshaw, J. D., Rice, M. E., and Hill, J. H. 2008. Evaluation of management strategies for bean leaf beetles (Coleoptera:Chrysomelidae) and Bean pod mottle virus (Comoviridae) in soybean. J. Econ. Entomol. 101:1211-1227.

4. Brunner, E., Domhof, S., and Langer, F. 2002. Nonparametric Analysis of Longitudinal Data in Factorial Experiments. John Wiley \& Sons, New York.

5. Cooper, R. L., and Hammond, R. B. 1999 
Registration of insect-resistant soybean germplasm lines HC95-24MB and HC95-15MB. Crop Sci. 39:599.

6. Cooper, R. L., Mendiola, T., St Martin, S. K., Fioritto, R. J., Schmitthenner, A. F., and Dorrance, A. E. 2001. Registration of 'Troll' soybean. Crop Sci. 41:922-923.

7. Dintinger, J., Boissot, N., Chiroleu, F., Hamon, P., and Reynaud, B. 2005. Evaluation of maize inbreds for Maize stripe virus and Maize mosaic virus resistance: disease progress in relation to time and the cumulative number of planthoppers. Phytopathology 95:600-607.

8. Dorrance, A. E., Gordon, D. T., Schmitthenner, A. F., and Grau, C. R. 2001. First report of Bean pod mottle virus in soybean in Ohio. Plant Dis. 85:1029.

9. Edwards, M. L., and Cooper, J. I. 1985. Plant virus detection using a new form of indirect ELISA. J. Virol. Methods 11:309-319.

10. Garrett, K. A., Madden, L. V., Hughes, G., and Pfender, W. F. 2004. New applications of statistical tools in plant pathology. Phytopathology 94:999-1003.

11. Giesler, L. J., Ghabrial, S. A., Hunt, T. E., and Hill, J. H. 2002. Bean pod mottle virus: a threat to US soybean production. Plant Dis. 86:1280-1289.

12. Hammond, R. B., Bierman, P., Levine, E., and Cooper, R. L. 2001. Field resistance of two soybean germplasm lines, HC95-15MB and HC95-24MB, against bean leaf beetle (Coleoptera:Chrysomelidae), western corn rootworm (Coleoptera:Chrysomelidae), and Japanese beetles (Coleoptera:Scarabaidae). J. Econ. Entomol. 94:1594-1601.

13. Hammond, R. B., and Cooper, R. L. 1999. Antibiosis of released soybean germplasm to Mexican bean beetle (Coleoptera:Coccinellidae). J. Entomol. Sci. 34:183-190.

14. Harvey, T. L., Martin, T. J., and Seifers, D. L. 1994. Importance of plant resistance to insect and mite vectors in controlling virus diseases of plants-resistance to the wheat curl mite
(Acari, Eriophyidae). J. Agric. Entomol. 11:271-277.

15. Hill, J. H., Koval, N. C., Gaska, J. M., and Grau, C. R. 2007. Identification of field tolerance to Bean pod mottle and Soybean mosaic viruses in soybean. Crop Sci. 47:212-218.

16. Hull, R. 2002. Matthew's Plant Virology. Academic Press, San Diego, CA.

17. Jeger, M. J., Holt, J., Van den Bosch, F., and Madden, L. V. 2004. Epidemiology of insecttransmitted plant viruses: modelling disease dynamics and control interventions. Physiol. Entomol. 29:291-304

18. Kang, B. C., Yeam, I., and Jahn, M. M. 2005. Genetics of plant virus resistance. Annu. Rev. Phytopathol. 43:581-621.

19. Krell, R. K., Pedigo, L. P., Hill, J. H., and Rice, M. E. 2004. Bean leaf beetle (Coleoptera:Chrysomelidae) management for reduction of Bean pod mottle virus. J. Econ. Entomol. 97:192-202.

20. Littell, R. C., Milliken, G. A., Stroup, W. W., Wolfinger, R. D., and Schabenberger, O. 2006. SAS System for Mixed Models, 2nd ed. SAS Institute, Inc., Cary, NC.

21. Madden, L. V., Hughes, G., and Irwin, M. E. 2000. Coupling disease-progress-curve and time-of-infection functions for predicting yield loss of crops. Phytopathology 90:788-800.

22. Madden, L. V., Hughes, G., and van den Bosch, F. 2007. The Study of Plant Disease Epidemics. American Phytopathological Society Press, St. Paul, MN.

23. McBlain, B. A., Fioritto, R. J., St. Martin, S. K., Calip-DuBois, A., Schmitthenner, A. F., Cooper, R. L., and Martin, R. J. 1990. Registration of Resnik soybean. Crop Sci. 30:424425 .

24. Moser, E. B. 1987. The analysis of mapped spatial point patterns. Pages 1141-1145 in: Proc. 12th SAS Users Int. Conf. SAS Institute, Cary, NC and Dallas, TX.

25. Pedersen, P., Gran, C., Cullen, E., and Hill, J. H. 2007. Potential for integrated management of soybean virus disease. Plant Dis. 91:12551259.

26. Reddy, M. S. S., Ghabrial, S. A., Redmond, C. T., Dinkins, R. D., and Collins, G. B. 2001 Resistance to Bean pod mottle virus in transgenic soybean lines expressing the capsid polyprotein. Phytopathology 91:831-838.

27. Ross, J. P. 1969. Effect of time and sequence of inoculation of soybeans with soybean mosaic and bean pod mottle viruses on yields and seed characters. Phytopathology 59:1404 1408

28. Ross, J. P. 1986. Response of early planted and late planted soybeans to natural infection by bean pod mottle virus. Plant Dis. 70:222-224.

29. Shah, D. A., and Madden, L. V. 2004. Nonparametric analysis of ordinal data in designed factorial experiments. Phytopathology 94:3343.

30. Slykhuis, J. T. 1967. Virus diseases of cereals. Rev. Appl. Mycol. 46:4011-4429.

31. Steinlage, T. A., Hill, J. H., and Nutter, F. W. 2002. Temporal and spatial spread of Soybean mosaic virus (SMV) in soybeans transformed with the coat protein gene of SMV. Phytopathology 92:478-486.

32. Sutula, C. L., Gillett, J. M., Morrissey, S. M., and Ramsdell, D. C. 1986. Interpreting ELISA data and establishing the positive-negative threshold. Plant Dis. 70:722-726.

33. Zheng, C. M., Chen, P. Y., Hymowitz, T. Wickizer, S., and Gergerich, R. 2005. Evaluation of Glycine species for resistance to Bean pod mottle virus. Crop Prot. 24:49-56.

34. Zhu, S., Walker, D. R., Boerma, H. R., All, J. N., and Parrott, W. A. 2006. Fine mapping of a major insect resistance QTL in soybean and its interaction with minor resistance QTLs. Crop Sci. 46:1094-1099.

35. Ziems, A. D., Giesler, L. J., Graef, G. L., Redinbaugh, M. G., Vacha, J. L., Berry, S. Madden, L. V., and Dorrance, A. E. 2007. Response of soybean cultivars to Bean pod mottle virus infection. Plant Dis. 91:719-726. 